EXPERIMENTAL STUDY

\title{
Evidence for functional CB1 cannabinoid receptor expressed in the rat thyroid
}

\author{
Anna Porcella, Giorgio Marchese ${ }^{1}$, Maria Antonietta Casu ${ }^{1}$, Antonio Rocchitta ${ }^{2}$, Maria Letizia Lai ${ }^{3}$, \\ Gian Luigi Gessa ${ }^{4}$ and Luca Pani \\ CNR Institute of Neurogenetics and Neuropharmacology, Cagliari, Monserrato, Italy, ${ }^{1}$ Neuroscienze S.c.a.r.l., Cagliari, Italy, ${ }^{2}$ Department of Sciences \\ applied to the Biosystems, University of Cagliari, Italy, ${ }^{3}$ Department of Cytomorphology, First Chair of Pathological Anatomy, Cagliari, Italy and \\ ${ }^{4}$ 'B B Brodie' Department of Neuroscience, University of Cagliari, Italy
}

(Correspondence should be addressed to A Porcella, CNR Institute for Neurogenetics and Neuropharmacology, c/o Cittadella Universitaria, S S 554 Km. 4.5 I-09042 Monserrato, Cagliari, Italy; Email: aporcell@unica.it)

\begin{abstract}
Objective: Previous reports have shown that the $\Delta^{9}$-tetrahydrocannabinol $\left(\Delta^{9} \mathrm{TCH}\right)$, the major psychoactive cannabinoid components of marijuana, is unable to inhibit thyroid hormonal activity. The aim of this study was to characterize the CB1 functional expression in the rat thyroid by a multi-methods approach.

Methods and Results: RT-PCR was used to detect the mRNA expression of the CB1 cannabinoid receptor (17.8 $\pm 4.0 \%$ of the normalizing reference gene $\beta_{2}$ microglobulin), as well as the expression of the endocannabinoid hydrolyzing enzyme, fatty acid amide hydrolase (46.9 $\pm 4.3 \%$ of $\beta_{2}$ microglobulin), in the rat thyroid gland.

The CB1-encoded protein was detected in its glycosylated form ( $63 \mathrm{kDa})$ by Western blot, employing a polyclonal antibody, while CB1 immunohistochemical localization showed an intracellular positive staining in both follicular and parafollicular cells. In addition, a 30\% decrease in serum levels of both $3,5,3^{\prime}$ tri-iodothyronine $\left(\mathrm{T}_{3}\right)$ and thyroxine $\left(\mathrm{T}_{4}\right)$ was detected $4 \mathrm{~h}$ after the administration of the synthetic cannabinoid receptor agonist, WIN 55,212-2 (10 mg/kg i.p.). These effects were antagonized by pretreatment with the CB1 antagonist SR 141716A (3 mg/kg i.p.); thyrotrophin levels were unaffected by both treatments.

Conclusion: These data indicate that functional CB1 receptors which are able to modulate the release of $\mathrm{T}_{3}$ and $\mathrm{T}_{4}$ are expressed in the rat thyroid, and suggest a possible role of cannabinoids in the regulation of rat thyroid hormonal activity.
\end{abstract}

European Journal of Endocrinology 147 255-261

\section{Introduction}

A significant part of the population uses marijuana during puberty and pregnancy, when perturbations in the endocrine system can have serious consequences (1). The major psychoactive cannabinoid component of marijuana, $\Delta^{9}$-tetrahydrocannabinol $\left(\Delta^{9} \mathrm{THC}\right)$, has been used in most of the studies investigating neuroendocrine function and regulation (1-4). However, the mechanism by which $\Delta^{9} \mathrm{THC}$ acts remained unclear until the brain cannabinoid receptor was discovered. Two cannabinoid receptor types - defined as CB1 (central) and CB2 (peripheral) - have been cloned and characterized both biochemically and pharmacologically (5-8). Their distribution has been mapped using different techniques, from which it has become clear that $\mathrm{CB} 1$ receptors are not exclusively localized in the brain but are also in many peripheral organs, whereas CB2 receptor distribution seems to be confined to cells and tissues derived from the immune system (9-15). Moreover, the recent discovery of an endogenous cannabinoid system (16) promoted a series of studies into its physiological role.

The widespread distribution of cannabinoid receptors, starting from the brain and spreading throughout the periphery, mirrors the variety of effects that $\Delta^{9} \mathrm{THC}$ and endocannabinoids, such as anandamide (16), produce at these different sites.

Various authors have described the inhibitory effect of $\Delta^{9} \mathrm{THC}$ on thyroid function $(1-4)$; this can be reversed by the administration of thyroid-stimulating hormone (TSH) (3). This suggested that the reduction in circulating TSH was the primary cause of the inhibition (3), which was succeeded in time by a reduction in serum 3,5,3' tri-iodothyronine $\left(\mathrm{T}_{3}\right)$ and serum thyroxine $\left(\mathrm{T}_{4}\right) \cdot \Delta^{9} \mathrm{THC}$, however, had no effect on the TSH response to exogenous thyrotrophin-releasing hormone (TRH) (1). 
Lesion studies in different hypothalamic subregions have indicated that $\Delta^{9} \mathrm{THC}$ also acts at the level of the caudal hypothalamus, either reducing TRH delivery or stimulating the release of a yet unidentified inhibitor of pituitary TSH release (3).

Studies concerning the direct effect of cannabinoids on thyroid hormone metabolism should now be reexamined, since the expression of $\mathrm{CB} 1$ receptors in both the rat hypothalamus and the pituitary gland $(9$, 10) has been reported.

Recently, Buckley et al. (13) described the presence of high levels of CB1 mRNA during the late embryological stages of the rat thyroid, using in situ hybridization histochemistry. Since very little is known, however, about CB1 expression and function in the adult rat thyroid, the purpose of this study was to better characterize them by a multi-method approach: reverse transcriptase-polymerase chain reaction (RT-PCR), Western blotting (WB) and immunohistochemistry. Furthermore, in order to elucidate the possible functional role of the $\mathrm{CB} 1$ receptors in the rat thyroid gland, we have studied the acute effects of the synthetic cannabinoid agonist WIN 55,212-2 and the CB1 antagonist SR 141716A on thyroid hormone activity.

\section{Materials and methods}

\section{Animals}

Sprague-Dawley rats were purchased from Charles River (Como, Italy). They were housed three or four per cage and given free access to food and water under controlled conditions of temperature $\left(22 \pm 2{ }^{\circ} \mathrm{C}\right)$ and humidity $(60 \pm 5 \%)$, with a $12 \mathrm{~h}$ light: $12 \mathrm{~h}$ darkness cycle. In order to minimize pain and discomfort for the animals, all the experiments were carried out in accordance with the EC regulation for the care and use of experimental animals (CEE No. 86/601). Rats were divided into groups of eight for each drug treatment. The experimental protocol consisted of four groups treated as follows: vehicle, WIN 55,212-2 $(10 \mathrm{mg} / \mathrm{kg})$, WIN 55,212-2 (10 mg/kg) + SR $141716 \mathrm{~A}$ $(3 \mathrm{mg} / \mathrm{kg})$ and SR $141716 \mathrm{~A}(3 \mathrm{mg} / \mathrm{kg})$. When SR $141716 \mathrm{~A}$ was administered in combination with WIN 55,212-2 it was given $15 \mathrm{~min}$ beforehand. All the drugs were administered i.p.

For the CB1 mRNA and protein studies, rats were killed by an overdose of equithesin $(5 \mathrm{mg} / \mathrm{kg}$ i.p.; containing $0.97 \%$ penthobarbital, $2.1 \%$ magnesium sulfate (both from Siegfried, Zofingen, Switzerland), $4.25 \%$ chloralhydrate, $42.8 \%$ propylene glycol and $11.46 \%$ ethanol (all from Sigma, Milan, Italy) and brain tissues, thyroid glands and livers were quickly dissected under a $100 \times$ stereomicroscope (Nikon, Tokyo, Japan). All the tissues were placed in sterile tubes and immediately stored at $-80^{\circ} \mathrm{C}$ until further processing, except for those used for mRNA extraction, which were processed immediately.

\section{Drugs and chemicals}

WIN 55,212-2 was purchased from Tocris Cookson Ltd (Avonmouth, Bristol, UK) while SR 141716A was a kind gift from Sanofi-Synthelabo (Bagneux, France). All these drugs were dissolved in $20 \mu$ l Tween 80 and $\mathrm{NaCl}(0.9 \%)$, which was also the composition of the vehicle.

\section{Radioimmunoassay (RIA)}

After habituation to the environment and depending on the experimental procedure, rats were killed as follows: $4 \mathrm{~h}$ after vehicle, WIN 55,212-2 (10 mg/kg), WIN $55,212-2(10 \mathrm{mg} / \mathrm{kg})+\mathrm{SR} 141716 \mathrm{~A}(3 \mathrm{mg} / \mathrm{kg})$ and SR $141716 \mathrm{~A}(3 \mathrm{mg} / \mathrm{kg})$ administration or $30 \mathrm{~min}$, $1 \mathrm{~h}, 2 \mathrm{~h}$ and $4 \mathrm{~h}$ after vehicle or WIN 55,212-2 $(10 \mathrm{mg} / \mathrm{kg})$ administration. Blood $(5 \mathrm{ml})$ was collected and then incubated for $30 \mathrm{~min}$ at $37^{\circ} \mathrm{C}$. Serum was separated after centrifugation at $3000 \boldsymbol{g}$ at room temperature for $10 \mathrm{~min}$.

TSH and free $\mathrm{T}_{3}$ and $\mathrm{T}_{4}$ were measured by RIA using a rat kit (BioChem Immuno Systems, S.p.A., Bologna, Italy) following the manufacturer's instructions. Results are expressed as $\mathrm{pg} / \mathrm{ml}$ for free $\mathrm{T}_{3}$ and $\mathrm{T}_{4}$ and $\mu \mathrm{IU} / \mathrm{ml}$ for $\mathrm{TSH}$.

\section{RNA extraction and CDNA synthesis}

Total RNA was extracted by Trizol reagent (Gibco BRLLife Technologies, Milan, Italy). DNAse treatment and cDNA synthesis were performed as previously described (17).

\section{PCR conditions}

We employed a PCR reaction to detect the amount of CB1 cannabinoid receptor and fatty acid amide hydrolase (FAAH) mRNA (18) using an endogenous sequence corresponding to the house-keeeping gene, rat $\beta_{2}$ microglobulin $\left(\beta_{2} \mathrm{~m}\right)$, as an internal standard. PCR reactions were performed as previously described (17). The primers used were: CB1 sense, 5'-catcatcatccacacgtcag- $3^{\prime}$ and CB1 antisense, 5'-atgctgttgtctagaggctg- $3^{\prime}$ yielding a $330 \mathrm{bp}$ fragment; FAAH sense, $5^{\prime}$-atggacagacggcagtgcag-3' and FAAH antisense, 5'ggcttcagcaggaggctcag- $3^{\prime}$ yielding a $460 \mathrm{bp}$ fragment; $\beta_{2} \mathrm{~m}$ sense, $5^{\prime}$-atctttctggtgcttgtctg- $3^{\prime}$ and $\beta_{2} \mathrm{~m}$ antisense, $5^{\prime}$-agtgtgagccaggatgatg-3' yielding a $243 \mathrm{bp}$ fragment.

\section{Analysis of PCR products}

After amplification, $25 \mu \mathrm{l}$ of each reaction was subjected to gel electrophoresis on a $1.8 \%$ agarose gel stained by ethidium bromide. Gels were visualized on a UV transilluminator (UVP, Upland, CA, USA), and image grabbing was achieved by a SONY XC-77CE 
CCD video camera module (SONY, Tokyo, Japan), connected to an MV-LC real time frame grabber acquisition board (Matrix Vision GmbH, Oppenweiler, Germany). Images were processed by Gel-Pro Plus RT-PCR gel analysis software (Media Cybernectis, Silver Spring, MD, USA). To correct for any variation in the RNA content and cDNA synthesis in the different preparations, each sample was normalized on the basis of the $\beta_{2} \mathrm{~m}$ gene content which was also evaluated, in parallel, in the exponential range. For comparative purposes, the CB1 mRNA contents were expressed relative to the $\beta_{2} \mathrm{~m}$ mRNA content in the same sample.

\section{Protein extraction}

Each tissue sample was homogenized at $4^{\circ} \mathrm{C}$ by immersing a sonication probe (Vibracell; Sonics \& Materials Inc., Danbury, CT, USA) for $10-15 \mathrm{~s}$ at $40 \%$ output in $100 \mu \mathrm{l} 20 \mathrm{mM}$ HEPES buffer (pH 7.9) containing $125 \mathrm{mM} \mathrm{NaCl}, 5 \mathrm{mM} \mathrm{MgCl}_{2}, 12 \%$ glycerol, $0.2 \mathrm{mM}$ EDTA, $0.1 \%$ Nonidet P-40, $5 \mathrm{mM}$ dithiothreitol, $0.5 \mathrm{mM}$ phenylmethylsulfonyl fluoride, $0.5 \mu \mathrm{g} / \mathrm{ml}$ leupeptin and $0.7 \mu \mathrm{g} / \mathrm{ml}$ pepstatin $\mathrm{A}$. The total protein extracts were then treated as previously described (19).

\section{One-dimensional WB}

SDS-stop solution (final concentration: 2\% SDS, 10\% glycerol and 5\% $\beta$-mercaptoethanol) was added to aliquots of tissue total extracts containing $30 \mu \mathrm{g}$ total protein. Samples were then treated as described (19). The blot was blocked with 5\% non-fat dry milk, and incubated with diluted CB1 (1:500) polyclonal antibodies from Biosource International, Inc. (Camarillo, CA, USA), followed by peroxidase-labelled antirabbit antibody (1:1500; Amersham Life Science, Milan, Italy). Immunoreactivity was visualized by enhanced chemiluminescence. A specificity control was run by preabsorbing $(1 \mathrm{~h})$ and co-incubating the antiserum (1:500) with the immunizing protein $(4 \mu \mathrm{g} / \mathrm{ml})$ (data not shown).

\section{Analysis of immunoblots}

Gels were visualized on the transilluminator and the images were processed with the aid of WB gel analysis software (Media Cybernectis). Each sample was measured on the basis of total absorbance in arbitrary units of optical density (OD).

\section{Immunohistochemistry}

Rats were anaesthetized with equithesin $(2.5 \mathrm{mg} / \mathrm{kg})$, perfused transcardically and fixed in $4 \%$ paraformaldehyde in $0.1 \%$ phosphate buffer (PB), pH 7.4. The thyroid, cerebellum and liver were then cryoprotected using a solution of $30 \%$ sucrose in $0.1 \mathrm{M} \mathrm{PB}$ at $4{ }^{\circ} \mathrm{C}$ overnight. Sections of $10 \mu \mathrm{m}$ were cut by cryostat
(Leica CM 3050), mounted on gelatin-coated glass slides, and cytochemical staining was performed. Briefly, after rinsing in phosphate-buffered saline with $0.2 \%$ Triton $\mathrm{X}-100(\mathrm{PBS}+\mathrm{T})$, the sections were incubated with $0.3 \% \mathrm{H}_{2} \mathrm{O}_{2}$ to eliminate endogenous peroxidase activity and, after extensive washing, in a blocking solution containing $1 \%$ bovine serum albumin and $20 \%$ normal goat serum in PBS+T. Sections were then incubated overnight at $4{ }^{\circ} \mathrm{C}$ with a $1: 100$ dilution of $\mathrm{CB} 1$ rabbit polyclonal antiserum from BioSource International, Inc. After rinsing, the sections were incubated with a goat anti-rabbit biotinylated IgG (1:200; Vector, Burlingame, CA, USA) for $1 \mathrm{~h}$, followed by an avidin-biotin complex (1:500; Vectastain ABC kit from Vector) for an additional hour. Sections were then exposed to $3,3^{\prime}$ diaminobenzidine containing cobalt chloride and nickel ammonium sulfate for $15 \mathrm{~min}$. The immunostaining was developed by adding $\mathrm{H}_{2} \mathrm{O}_{2}$. Finally, after washing in PBS+T, nuclei were counterstained with haematoxylin and eosin and all sections were dehydrated in ascending concentrations of ethanol, cleared with xylene and coverslipped with Entellan (Sigma) before observation by light microscopy (Olympus BX60).

\section{Statistical analysis}

TSH and free $\mathrm{T}_{3}$ and $\mathrm{T}_{4}$ data were evaluated by oneway analysis of variance (ANOVA) or two-way ANOVA where more appropriate, followed by the Newman-Keuls test for post hoc comparisons.

\section{Results}

The specificity of amplification for CB1 was primarily established using DNA from plasmids which only express CB1 (data not shown), as previously reported (17). The expression levels of $\mathrm{CB} 1, \mathrm{FAAH}$ and $\beta_{2} \mathrm{~m}$ genes in each sample were determined by relative measurements of mRNA-derived cDNA using RT-PCR. The mRNA levels of CB1 and FAAH were expressed relative to the $\beta_{2} \mathrm{~m}$ mRNA, thus allowing the comparison of CB1 and FAAH with $\beta_{2} \mathrm{~m}$ (Fig. 1). CB1 expression level was detected in the rat thyroid (17.8 $\pm 4.0 \%$ of $\left.\beta_{2} \mathrm{~m}\right)$ and cerebellum $(60.6 \pm 8.0 \%$ of $\left.\beta_{2} \mathrm{~m}\right)$; the liver was used as a negative control tissue and no signal was detected (Fig. 1). FAAH expression profile was also analyzed in the rat thyroid $\left(46.9 \pm 4.3 \%\right.$ of $\left.\beta_{2} \mathrm{~m}\right)$, cerebellum $(87.7 \pm 7.2 \%$ of $\beta_{2} \mathrm{~m}$ ) and liver (176.6 $\pm 12.6 \%$ of $\beta_{2} \mathrm{~m}$ ) (Fig. 1).

Figure $2 \mathrm{~A}$ shows a representative $\mathrm{WB}$ with an affinity-purified antibody raised against the N-terminus of the CB1 receptor, detecting one major band of approximately $63 \mathrm{kDa}$ which gave an OD reading (Fig. 2B) in the thyroid of $97.5 \pm 14.9$ arbitrary units (a.u.) and in the cerebellum of $489.2 \pm 23$ a.u.; the liver was used as a negative control and the CB1 protein 
A

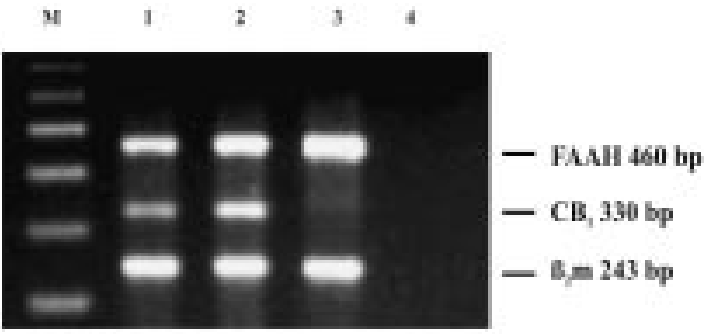

B

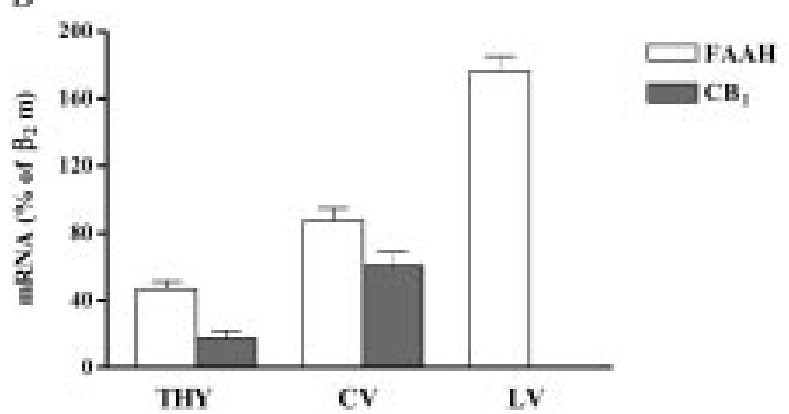

Figure 1 (A) RT-PCR of CB1, fatty acid amide hydrolase (FAAH) and $\beta_{2}$ microglobulin $\left(\beta_{2} m\right)$ mRNA from rat thyroid (lane 1), cerebellum (lane 2), liver (lane 3 ) and negative control (lane 4) run on $1.8 \%$ agarose gel. (B) Relative differences of $\mathrm{CB} 1$ transcripts in rat thyroid (THY), cerebellum (CV) and liver (LV). CB1 and FAAH mRNA relative contents were normalized with that of $\beta_{2} m$ and expressed relative to the $\beta_{2} \mathrm{~m}$ mRNA level. Values are means \pm S.E.M.; $n=4$. The levels of CB1 mRNA in the thyroid $\left(17.8 \pm 4.5 \%\right.$ of $\left.\beta_{2} \mathrm{~m}\right)$ and the cerebellum $\left(60.6 \pm 8.9 \%\right.$ of $\left.\beta_{2} \mathrm{~m}\right)$ were measured by RT-PCR. In the liver, as expected, no CB1 expression was detected. The levels of FAAH mRNA in the thyroid $\left(46.9 \pm 4.3 \%\right.$ of $\left.\beta_{2} \mathrm{~m}\right)$, in the cerebellum $\left(87.7 \pm 7.2 \%\right.$ of $\left.\beta_{2} \mathrm{~m}\right)$ and in the liver $\left(176.6 \pm 12.6 \%\right.$ of $\left.\beta_{2} \mathrm{~m}\right)$ were measured by RTPCR.

was not present in this tissue. The $63 \mathrm{kDa}$ major band corresponds to the expected molecular weight of the glycosylated form of the CB1 receptor (20-22). A specificity control experiment, done by incubating the CB1 antibody with the immunizing protein, showed no immunoreactivity (data not shown), as previously described (22).

Immunohistochemistry was also performed on the rat thyroid with the same antibody, and multiple CB1-positive granules were present in the intracellular region of follicular and parafollicular cells (Fig. 3A); uniform intense CB1 staining was exhibited in the cerebellum molecular layer, while moderate positivity was present in the granular layer (Fig. 3C). Standard haematoxylin and eosin staining was also performed in order to check the histological pattern of the thyroids used for this study (data not shown). In addition, a negative control experiment with no $\mathrm{CB} 1$ antibody incubation showed the expected absence of positive staining in the liver (data not shown), thyroid and cerebellum (Fig. 3B and D).
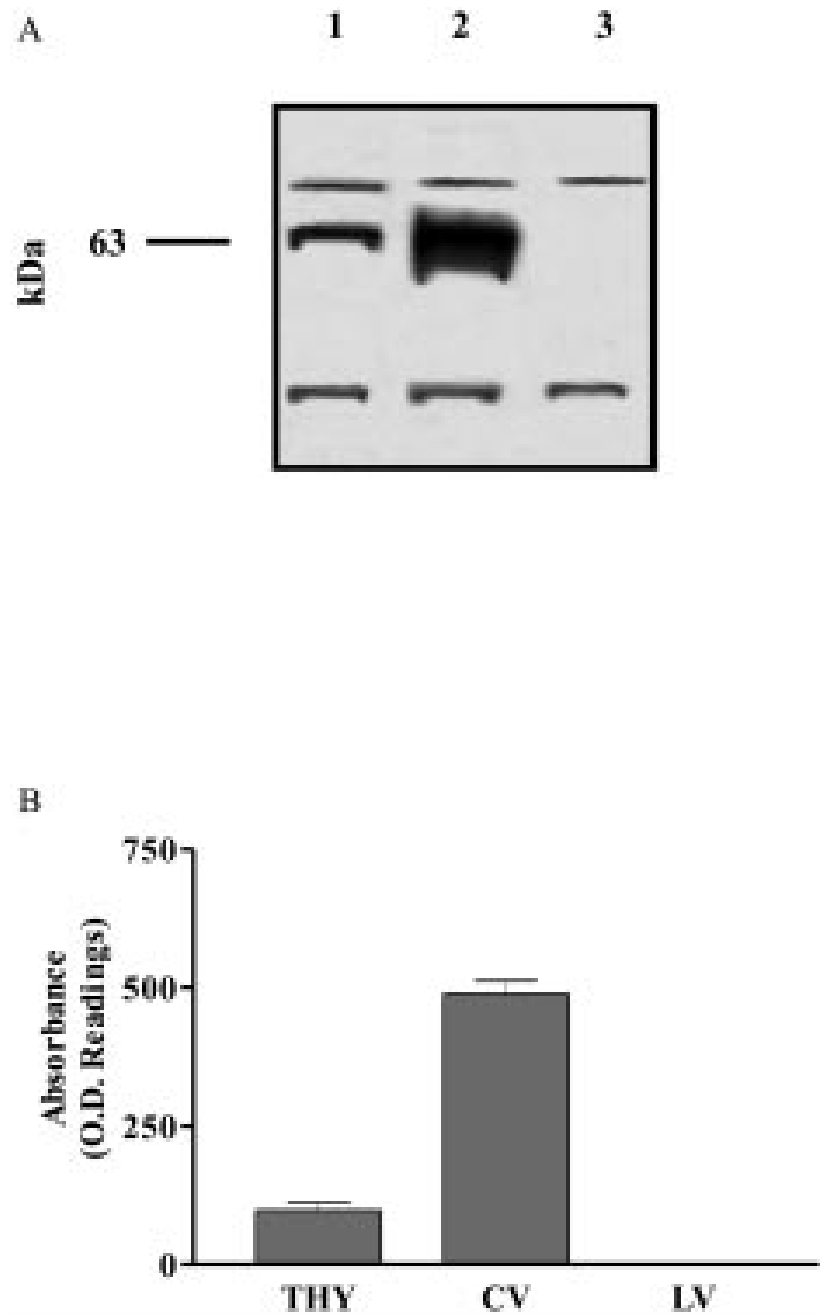

Figure 2 (A) WB of whole cell extracts obtained from rat thyroid, cerebellum and liver. One major specific band of $63 \mathrm{kDa}$ was recognized in rat thyroid and cerebellum (lanes 1 and 2) while in the liver, as expected, the CB1 protein was not detectable (lane 3). (B) Relative differences of CB1 protein expression in the rat thyroid (THY) and cerebellum (CV). The level of CB1 proteins was measured in a.u. of OD values and compared. Values are means \pm S.E.M.; $n=4$. CB1 protein levels were determined in the rat thyroid (97.5 \pm 14.9 a.u.) and in the cerebellum (489.2 \pm 23 a.u.).

The effects on TSH and free $\mathrm{T}_{3}$ and $\mathrm{T}_{4}$ serum levels $4 \mathrm{~h}$ after pretreatment with WIN 55,212-2 $(10 \mathrm{mg} / \mathrm{kg}), \quad$ WIN $\quad 55,212-2 \quad(10 \mathrm{mg} \quad / \mathrm{kg})+\mathrm{SR}$ $141716 \mathrm{~A}(3 \mathrm{mg} / \mathrm{kg})$ and SR $141716 \mathrm{~A}(3 \mathrm{mg} / \mathrm{kg})$ were determined. TSH levels were unchanged (one-way ANOVA $\left.\mathrm{F}_{3,28}=0.77, P>0.05\right)$ after all drug treatments (Fig. 4A). A significant difference between groups was observed in free $\mathrm{T}_{3}$ serum level (one-way ANOVA $\left.\mathrm{F}_{3,28}=4.812, P<0.001\right)$ and a significant decrease was detected after WIN 55,212-2 $(10 \mathrm{mg} / \mathrm{kg})$ compared with vehicle $(P<0.01)$; this effect was antagonized by a pretreatment with SR $141716 \mathrm{~A} \mathrm{(3} \mathrm{mg/kg)} \mathrm{(Fig.} \mathrm{4B).} \mathrm{A} \mathrm{significant} \mathrm{difference}$ between groups was also observed in free $\mathrm{T}_{4}$ serum levels (one-way ANOVA $\mathrm{F}_{3,28}=3.957, \mathrm{P}<0.05$ ) and 

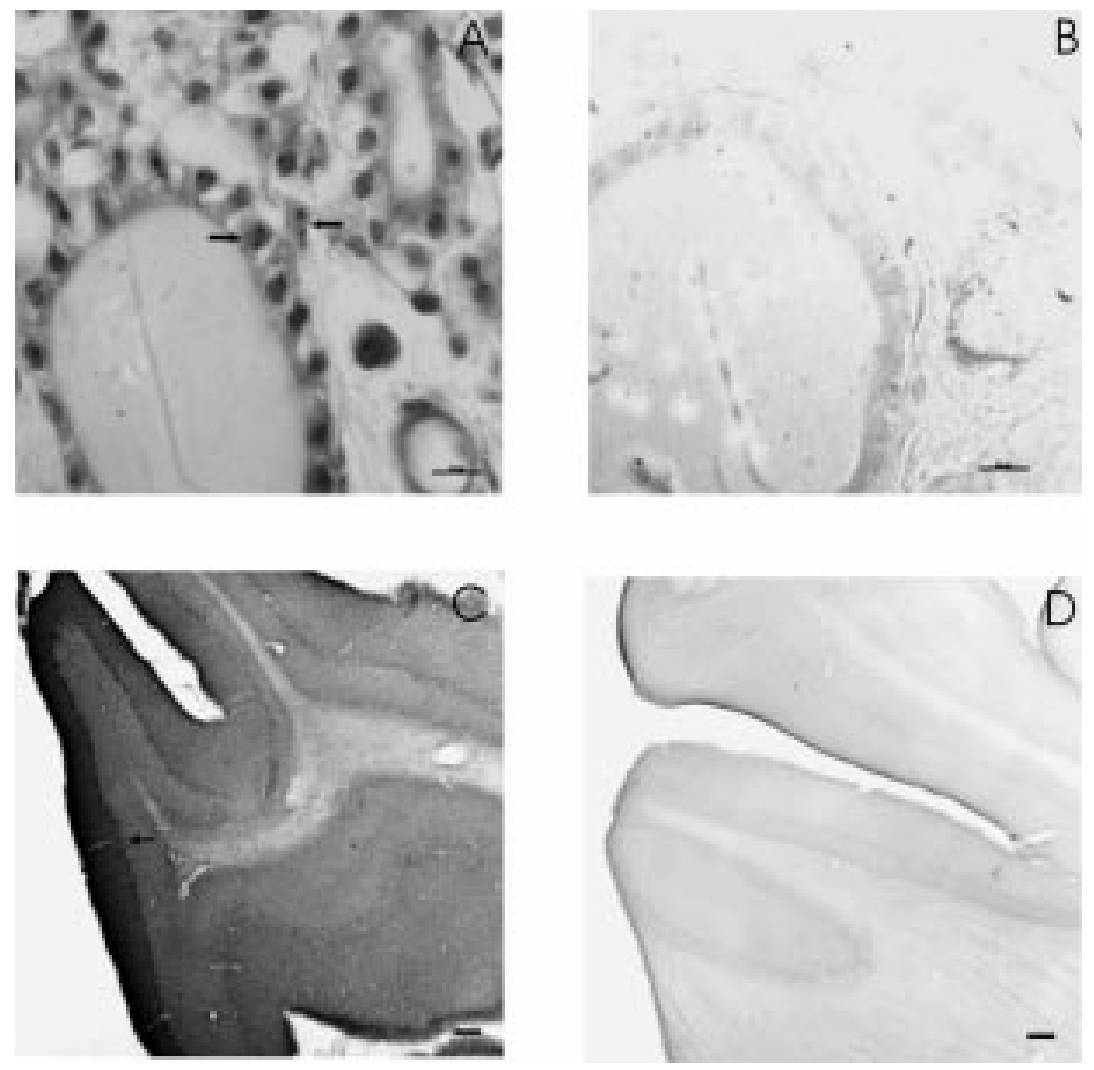

Figure 3 (A) Arrows show intracellular positive staining in the follicular and parafollicular cells in the rat thyroid. (B) Negative control experiment with no antibody incubation showing the absence of positive staining in the rat thyroid. (C) Arrow shows CB1-positive staining in the molecular layer of the cerebellum and moderate positivity in the granular layer. (D) Negative control experiment with no antibody incubation showing the absence of positive staining in the rat cerebellum. Scale bars $=$ $10 \mu \mathrm{m}(\mathrm{A}$ and $\mathrm{B}) ; 100 \mu \mathrm{m}$ (C and D).

a significant decrease was detected after WIN 55,212-2 $(10 \mathrm{mg} / \mathrm{kg})$ compared with vehicle $(P<0.05)$; this effect was antagonized by pretreatment with SR $141716 \mathrm{~A} \mathrm{(3} \mathrm{mg/kg)} \mathrm{(Fig.} \mathrm{4C).}$

TSH levels were also measured after $30 \mathrm{~min}, 1 \mathrm{~h}, 2 \mathrm{~h}$ and $4 \mathrm{~h}$ of WIN $55,212-2(10 \mathrm{mg} / \mathrm{kg})$ or vehicle administration; no significant differences (two-way ANOVA $\left.\mathrm{F}_{1,14}=2.123, P>0.05\right)$ were found between groups (data not shown).

\section{Discussion}

In this study we demonstrated the presence of cannabinoid CB1 mRNA and protein in the adult rat thyroid. Although the presence of thyroid CB1 mRNA has previously been described by in situ immunohistochemistry during the late stages of rat embryological development (13), this is the first time that the CB1 mRNA was detectable in the adult rat by RT-PCR; in fact, in a previous study - in which the same sensitive technique was used - the CB1 message proved undetectable (9). We believe that this difference is due to a number of technical improvements that we have made in the tissue preparation, and in the extraction of total RNA. Indeed, we processed all the samples that we used for the RNA studies immediately, avoiding tissue thawing and any delay in further processing that could account for mRNA degradation. The levels of CB1
mRNA in the thyroid gland were much lower than those in brain areas such as the cerebellum or cerebral cortex; this is consistent with previous studies showing that, in the periphery, the highest contents of $\mathrm{CB} 1$ mRNA are found in the pituitary gland, B cells and natural killer cells (9).

We used the liver as a negative control, confirming the fact that in this tissue CB1 mRNA is not present (9), and strengthening the signal specificity that we found in the thyroid. We also analyzed the mRNA expression of FAAH, the enzyme which hydrolizes the endocannabinoids in the cell (18). The presence of FAAH mRNA in the thyroid supports the possibility that an endocannabinoid system could exist in this gland. Indeed, FAAH is expressed in many peripheral organs and in most cases CB1 receptors are also coexpressed (18). However, in the liver, which we used as a negative control for CB1 expression, FAAH is highly expressed. This can be explained by the fact that in the rat liver FAAH can metabolize substrates other than those which are present in the rat brain (18).

In order to check whether the $\mathrm{CB} 1$ gene was not only transcribed but also translated in the thyroid, we performed $\mathrm{WB}$, probing the blot with a polyclonal affinity-purified antibody raised against the CB1 amino terminus. This antibody recognized the $\mathrm{CB} 1$ protein in its glycosylated form (63 kDa) $(20-22)$ in both rat thyroid and cerebellum total extracts, while, as 


\section{TSH}

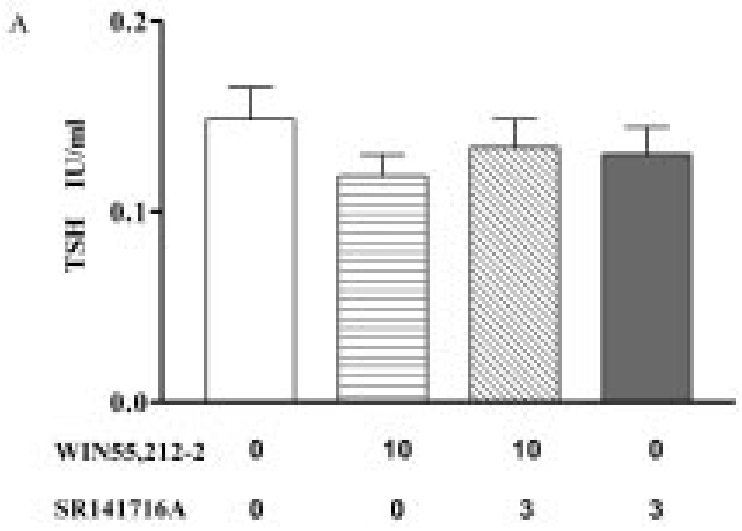

$\mathbf{T 3}$

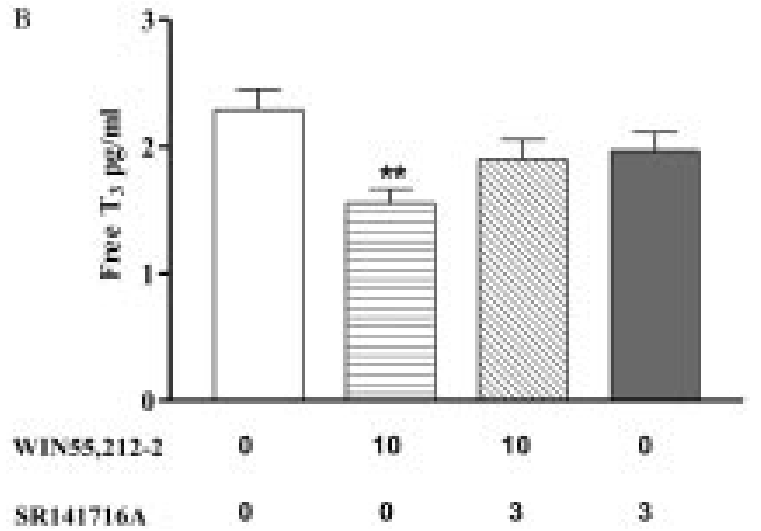

T4

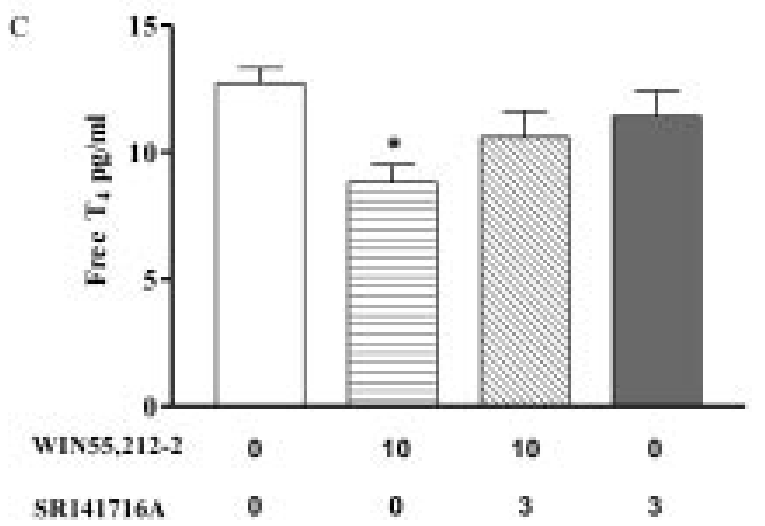

Figure 4 Effects of the combination of WIN 55,212-2 (10 mg/kg i.p.) and SR $141716 \mathrm{~A}\left(3 \mathrm{mg} / \mathrm{kg}\right.$ i.p.) on TSH (A), free $\mathrm{T}_{3}(\mathrm{~B})$ and free $\mathrm{T}_{4}(\mathrm{C})$ serum levels measured $4 \mathrm{~h}$ after WIN 55,212-2 administration; SR141716A was administered 15 min before WIN $55,212-2$. Each bar is the mean \pm S.E.M. of eight rats. ${ }^{*} P<0.05$ and ${ }^{*} P<0.01$ compared with vehicle-treated rats (NewmanKeuls test). expected, in the liver CB1 protein expression was absent.

In addition, when we studied the CB1 cellular distribution within the rat thyroid using immunohistochemistry, we found intracellular positive staining in the follicular and parafollicular cells. Specific CB1 intense staining was detectable in histological sections of the cerebellum, which we ran in parallel as positive controls. Furthermore, the liver was used as a negative control and no staining was detected (data not shown).

Given the fact that all the functional effects exerted by cannabinoids and endocannabinoids are mostly receptor mediated, we decided to study the acute effect of $10 \mathrm{mg} / \mathrm{kg}$ WIN $55,212-2$ on TSH and free $\mathrm{T}_{3}$ and $\mathrm{T}_{4}$ levels. Decreased free $\mathrm{T}_{3}(-32 \%)$ and $\mathrm{T}_{4}$ $(-30 \%)$ serum levels were observed $4 \mathrm{~h}$ after $10 \mathrm{mg} / \mathrm{kg}$ WIN 55,212-2. These effects were antagonized by a $15-\mathrm{min}$ pretreatment with $3 \mathrm{mg} / \mathrm{kg}$ of the specific CB1 antagonist SR 141716A, suggesting that the thyroid CB1 receptors could be involved in the regulation of the release of these hormones. It must be considered that WIN 55,212-2 binds with markedly higher affinity to $\mathrm{CB} 2$ receptors than $\mathrm{CB} 1$; therefore, until CB2 expression is studied in the rat thyroid, we cannot exclude the possibility that the above-described effects may also be mediated by $\mathrm{CB} 2$ receptors. However, the effect of WIN 55,212-2 on free $\mathrm{T}_{3}$ and $\mathrm{T}_{4}$ levels was fully antagonized by the specific CB1 antagonist SR $141716 \mathrm{~A}$ and this indicates a CB1- rather than a CB2-mediated control of rat thyroid hormone release. The fact that TSH levels were not affected by either $10 \mathrm{mg} / \mathrm{kg}$ WIN $55,212-2$ or $3 \mathrm{mg} / \mathrm{kg}$ SR $141716 \mathrm{~A}$ suggests that the decrease of $\mathrm{T}_{3}$ and $\mathrm{T}_{4}$ is probably due to a direct effect on the thyroid CB1 receptors rather than a lack of TSH modulation. Our data showed that WIN 55,212-2 was not able to affect the serum TSH levels at any of the analyzed time-points (30 min, $1 \mathrm{~h}, 2 \mathrm{~h}, 4 \mathrm{~h}$ ); however, we cannot exclude the possibility that a decrease in TSH levels could occur later than $4 \mathrm{~h}$ after WIN 55,212-2 administration. The fact that in a previous study $\Delta^{9} \mathrm{THC}$ was able to decrease TSH levels very rapidly (1) shows that $\Delta^{9}$ THC and WIN 55,212-2, having different pharmacokinetic and metabolic profiles $(8,23,24)$, can act on the pituitary $\mathrm{CB} 1$ receptors with divergent mechanisms of action.

The molecular and functional evidence shown in this paper strongly suggests the fact that cannabinoids may have a direct acute influence on rat thyroid hormone activity. Further studies of the chronic effect of cannabinoids on thyroid function are needed, since these drugs are usually abused over long periods of time.

\section{Acknowledgements}

This work was supported by a grant from the National Research Council, Italy; it was also partially supported by the Regione Sardegna. 


\section{References}

1 Hillard JC, Farber NE, Hagen TC \& Bloom AS. The effect of $\Delta^{9}-$ tetrahydrocannabinol on serum thyrotropin levels in the rat. Pharmacology Biochemistry and Behavior 198420 547-550.

2 Rosenkranz H \& Esber HJ. Cannabinoid induced hormone changes in monkeys and rats. Journal of Toxicology and Environmental Health $19806297-313$.

3 Lomax P. The effect of marihuana on pituitary-thyroid activity in the rat. Agent and Actions $19701252-257$.

4 Nazar B, Kairys DJ, Fowler R \& Harclerode J. Effects of $\Delta^{9}$-tetrahydrocannabinol on serum-thyroxine concentrations in the rat. Journal of Pharmacy and Pharmacology 197829 778-779.

5 Matsuda LA, Lolait SJ, Brownstein MJ, Young AC \& Bonner TI. Structure of cannabinoid receptor and functional expression of the cloned cDNA. Nature 1990346 561-564.

6 Gerard C, Mollereau C, Vassart G \& Parmentier M. Nucleotide sequence of a human cannabinoid receptor cDNA. Nucleic Acids Research $1990187142-7148$

7 Munro S, Thomas KL \& Abu-Shire M. Molecular characterization of a peripheral receptor for cannabinoids. Nature $1993 \mathbf{3 6 5}$ 61-65.

8 Ameri A. The effects of cannabinoids on the brain. Progress in Neurobiology 199958 315-348.

9 Galiègue S, Mary S, Marchand J, Dussossoy D, Carrière D, Carayon PM et al. Expression of central and peripheral cannabinoid receptor in human immune tissues and leukocyte subpopulations. European Journal of Biochemistry 1995232 54-61.

10 Dove Pettit DA, Harrison MP, Olson JM, Spencer RF \& Cabral GA. Immunohistochemical localization of the neural cannabinoid receptor in the rat brain. Journal of Neuroscience Research 1998 $51391-402$

11 Herkenham M, Lynn AB, Johnson MR, Melvin LS, De Costa BR \& Rice KC. Characterization and localization of cannabinoid receptors in the rat brain: a quantitative in vitro autoradiographic study. Journal of Neuroscience 199111 563-583.

12 Tsou K, Brown S, Sañudo-Peña MC, Mackie K \& Walker JM. Immunohistochemical distribution of cannabinoid CB1 receptors in the rat central nervous system. Neuroscience $1998 \mathbf{8 3}$ 393-411.

13 Buckley NE, Hansson S, Harta G \& Mezey E. Expression of the CB1 and $\mathrm{CB} 2$ receptor messenger RNAs during embryonic development in the rat. Neuroscience 199882 1131-1149.
14 Mailleux P \& Vanderhaeghen JJ. Distribution of neuronal cannabinoid receptor in the adult rat brain: a comparative receptor binding radioautography and in situ hydridization histochemistry. Neuroscience $1992 \mathbf{4 8} 655-668$.

15 Matsuda LA, Bonner TI \& Lolait SJ. Localization of cannabinoid receptor mRNA in rat brain. Journal of Comparative Neurology $1993327535-550$.

16 Devane WA, Hanus L, Breuer A, Pertwee RG, Stevenson LA, Griffin $\mathrm{G}$ et al. Isolation and structure of a brain constituent that binds to the cannabinoid receptor. Science 1992258 1946-1949.

17 Porcella A, Casellas P, Gessa GL \& Pani L. Cannabinoid receptor CB1 mRNA is highly expressed in the rat ciliary body: implications for the antiglaucoma properties of marihuana. Molecular Brain Research 199858 240-245.

18 Ueda N, Puffenbarger RA, Yamamoto S \& Deutsch DG. The fatty acid amide hydrolase (FAAH). Chemistry and Physics of Lipids 2000108 107-121.

19 Porcella A, Gessa GL \& Pani L. $\Delta^{9}$-Tetrahydrocannabinol increases sequence specific AP1 DNA-binding activity and Fosrelated antigens in the rat brain. European Journal of Neuroscience $1998101743-1751$.

20 Song C \& Howlett A. Rat brain cannabinoid receptors are Nlinked glycosilated proteins. Life Sciences 199556 1983-1989.

21 Howlett AC, Song C, Berglund BA, Wilken GH \& Pigg JJ. Characterization of $\mathrm{C}_{1}$ cannabinoid receptors using receptor peptide fragments and site-directed antibodies. Molecular Pharmacology 1998 53 504-510.

22 Porcella A, Maxia C, Gessa GL \& Pani L. The human eye expresses high levels of $\mathrm{CB} 1$ cannabinoid receptor mRNA and protein. European Journal of Neuroscience 200012 1123-1127.

23 Pertwee RG. Pharmacology of cannabinoid $\mathrm{CB}_{1}$ and $\mathrm{CB}_{2}$ receptors. Pharmacology and Therapeutics $1997 \mathbf{7 4} 129-180$.

24 Petitet F, Jeantaud B, Bertrand P \& Imperato A. Cannabinoid penetration into mouse brain as determined by ex vivo binding. European Journal of Pharmacology 1999 374 417-421.

Received 19 February 2002

Accepted 10 April 2002 